See Article page e377.

\section{Commentary: The flapping wings of a butterfly; discovering the onset of atherosclerosis}

\author{
Ari A. Mennander, MD, PhD
}

How can a smallest of details initiate a sequence of events leading to a ubiquitous catastrophe? One may argue that this scenario - also known as the butterfly effect theoryis simply bad luck or exaggeration and story making. ${ }^{1}$ Can a smaller-than-microscopic particle like nuclear factor $-\kappa \mathrm{B}(\mathrm{NF}-\kappa \mathrm{B})$ really induce worldwide atherosclerosis that in turn kills many, especially in the Western world?

Rao and colleagues ${ }^{2}$ investigated the impact of nucleophosmin and its association with activating the NF- $\kappa \mathrm{B}$ pathway, which mediates vascular inflammation and endothelial dysfunction. Atherosclerotic-like lesions were investigated using several experimental in vivo and in vitro models. Quantification of the results was professionally recorded using sophisticated software means. Different downstream target genes associated with atherosclerosis were superbly investigated during interaction and deactivation of nucleophosmin with NF- $\kappa \mathrm{B}$. Taken together, there is an abundance of information to be digested: nucleophosmin was found in the atherosclerotic lesions, and suppression of nucleophosmin decreased macrophage infiltration and seemed to improve plaque stability.

Is it a matter of perception whether a single molecule may become so important that a whole article is dedicated to its impact on atherosclerosis? In addition to the $\mathrm{NF}-\kappa \mathrm{B}$ pathway, nucleophosmin may interact with insulin, affecting cholesterol metabolism and glucose concentration; maybe some other yet-unknown pathways are also involved. ${ }^{3}$ The reduced macrophage infiltration may be difficult to interpret, since there is no separate investigation of macrophages M1 and M2, which have different roles during inflammation, tissue repair, and remodeling ${ }^{4}$; the role of macrophage infiltration in this study may need additional means besides using only CD68 as a generalized macrophage marker. Although nucleophosmin is predominantly

From Tampere University Heart Hospital and Tampere University, Tampere, Finland. Disclosures: Author has nothing to disclose with regard to commercial support.

Received for publication Oct 22, 2019; revisions received Oct 22, 2019; accepted for publication Oct 22, 2019; available ahead of print Nov 7, 2019.

Address for reprints: Ari A. Mennander, MD, PhD, Tampere University Heart Hospital, SDSKIR, PL 2000, Tampere, Finland (E-mail: ari.mennander@sydansairaala. fi).

J Thorac Cardiovasc Surg 2021;161:e395-6

$0022-5223 / \$ 36.00$

Copyright (C) 2019 by The American Association for Thoracic Surgery

https://doi.org/10.1016/j.jtcvs.2019.10.118



CENTRAL MESSAGE

The butterfly effect-a small molecular change leads to immense consequences.

situated within CD31-positive cells, this may not be suggestive for only proinflammatory mechanisms involving endothelial cells. ${ }^{5}$ Plaque instability is difficult to prove using these experimental approaches, and the impact of nucleophosmin on stability of the atherosclerotic lesion is only assumptive. Most of all, the interaction between nucleophosmin and NF- $\kappa \mathrm{B}$ may have potential risk of malignancies, as increased and decreased nucleophosmin levels have both been reported to be associated with cancer ${ }^{6}$; the clinical implication of this study remains undetermined.

Looking from the shore, a transatlantic ship in the horizon advances slowly and may figuratively represent research on atherosclerosis, but searching the core of the cells and molecular pathways is like being on that ship itself; progression seems inevitable from a single point of view and drives us fast toward a dream of solving any disease entity. Nucleophosmin may be a new treatment target against atherosclerosis; monoclonal antibodies or gene editing for targeting nucleophosmin may in future add to the picture. Although the development of atherosclerosis seems complex, involving many signaling pathways and mechanisms, there may be many ships in the horizon aiming for a mutual solution of decoding atherosclerosis. Similarly, there may be many butterflies flapping their wings together, thus leading to a cascade of events revealing the way to treat atherosclerosis. The exemplary study by Rao and colleagues may also in future excitingly link research on cancer mechanisms with those of atherosclerosis.

\section{References}

1. Clatici VG, Satolli F, Tatu AL, Voicu C, Draganita AMV, Lotti T. Butterfly effect-the concept and the implications in dermatology, acne, and rosacea. $J$ Clin Med. 2018;13:89-94. 
2. Rao C, Liu B, Huang D, Chen R, Huang K, Li F, et al. Nucleophosmin contributes to vascular inflammation and endothelial dysfunction in atherosclerosis progression. J Thorac Cardiovasc Surg. 2021; 161:e377-93.

3. Wang X, Ma H, Wang X. Nucleophosmin/B23 contributes to hepatic insulin resistance through the modulation of NF- $\kappa \mathrm{B}$ pathway. Biochem Biophys Res Commun. 2019;511:214-20.
4. Poston RN. Atherosclerosis: integration of its pathogenesis as a self-perpetuating propagating inflammation: a review. Cardiovasc Endocrinol Metab. 2019;8:51-61.

5. Privratsky JR, Newman DK, Newman PJ. PECAM-1: conflicts of interest in inflammation. Life Sci. 2010;17:69-82.

6. Box JK, Paquet N, Adams MN, Boucher D, Bolderson E, O'Byrne KJ, et al. Nucleophosmin: from structure and function to disease development. BMC Mol Biol. 2016;24:1-12.
See Article page e377.

\section{Commentary: Unraveling the mysteries of atherogenesis: An elusive goal}

\author{
Darrell $\mathrm{Wu}, \mathrm{MD},{ }^{\mathrm{a}}$ and Shuab Omer, $\mathrm{MD}^{\mathrm{b}}$
}

Endothelial activation, which involves alterations in chemokine receptor activity, endothelial permeability, and paracrine factor secretion, is a central hallmark of vascular inflammation, ${ }^{1}$ which in turn is a critical step in the pathogenesis of atherogenesis. Increasing evidence shows that endothelial activation is nuclear factor $\kappa$ light chain enhancer of activated B cells (NF-kB)-dependent. NF-kB activation can lead to an inflammatory phenotypic change through transcription of genes associated with chemokines, adhesion molecules, and cytokines. ${ }^{2}$

Nucleophosmin (NPM) is a multifunctional nuclear phosphoprotein that has been implicated in multiple pathways, such as transcriptional gene regulation, ribosome biogenesis, DNA repair processes, apoptosis, and cell differentiation. ${ }^{2}$ Although the function of NPM in the oxidative stress response is known, the function of NPM in arterial vascular pathogenesis is not as well characterized. ${ }^{3}$ In this issue of the Journal, Rao and colleagues ${ }^{4}$ have

From the a Division of Cardiothoracic Surgery, Baylor College of Medicine, Houston and ${ }^{b}$ Department of Advanced Cardiopulmonary Therapies and Transplantation, The University of Texas Health Science Center at Houston, McGovern Medical School, Houston, Tex.

Disclosures: Authors have nothing to disclose with regard to commercial support.

Received for publication Oct 26, 2019; revisions received Oct 28, 2019; accepted for publication Oct 30, 2019; available ahead of print Nov 28, 2019.

Address for reprints: Shuab Omer, MD, Department of Advanced Cardiopulmonary Therapies and Transplantation, The University of Texas Health Science Center at Houston, McGovern Medical School, Houston, TX 77030 (E-mail: shuab.omer@ uth.thc.edu).

J Thorac Cardiovasc Surg 2021;161:e396-7

$0022-5223 / \$ 36.00$

Copyright (c) 2019 by The American Association for Thoracic Surgery

https://doi.org/10.1016/j.jtcvs.2019.10.199
Check for updates

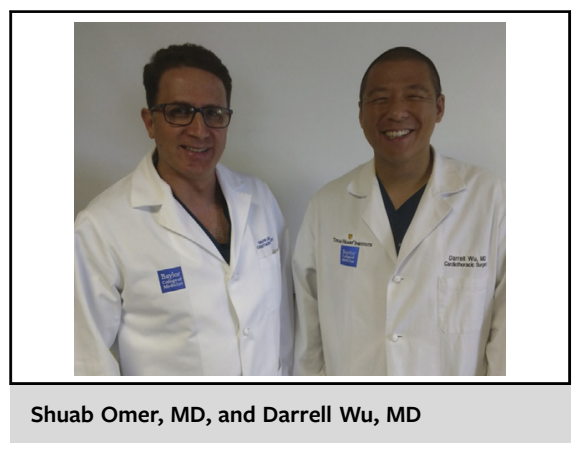

CENTRAL MESSAGE

Nucloephosmin promotes

vascular inflammation and endo-

thelial dysfunction in an NF-kB

dependent pathway.

attempted to elucidate the role of NPM in vascular inflammation and the progression of atherogenesis.

The authors first used human atherosclerotic plaques to demonstrate that, compared with aortic tissue from patients needing aortic valve replacement, NPM levels were increased and colocalized to endothelial cells. Second, they found that injection of adenovirus containing NPM shRNA into $\mathrm{ApoE}^{-/-}$mice fed a high-fat diet and knockdown of NPM attenuated atherosclerotic lesion formation, reduced vascular inflammation, and decreased NK-kB p65 phosphorylation. Third, using an in vitro model consisting of human umbilical vein endothelial cells, they found that stimulation with palmitic acid increased NPM levels and induced the expression of inflammatory cytokines, whereas NPM knockdown with siRNA attenuated this effect. Furthermore, they found that NPM physically interacted with the NF-kB p65 subunit, promoted its nuclear transposition, and increased the transcriptional activity of NF-kB promoter and enhanced binding to proinflammatory target genes, such as ICAM-1, E-selectin, IL-Ib, and IL-6. 